\title{
Efek Kardioprotektif Ekstrak Daun Kenikir (Cosmos Caudatus Kunth.) pada Tikus Putih (Rattus norvegicus) Model Diabetes Mellitus
}

\author{
Tri Agusti Sholikah ${ }^{*}$, Sri Wulandari², Taufik Ridwan Hadi Kusuma ${ }^{3}$, \\ Muthmainah $^{1}$
}

1.Bagian Histologi, Fakultas Kedokteran Universitas Sebelas Maret, Surakarta

2.Bagian Fisiologi, Fakultas Kedokteran Universitas Sebelas Maret, Surakarta

3.Fakultas Kedokteran Universitas Sebelas Maret, Surakarta

Korespondensi : triagusti_sholikah@staff.uns.ac.id

\begin{abstract}
ABSTRAK
Latar Belakang : Diabetes mellitus (DM) merupakan salah satu penyakit degeneratif yang dapat menyebabkan komplikasi serius pada berbagai organ tubuh termasuk jantung. Oleh karena itu, DM harus diterapi dengan adekuat untuk mencegah progesifitas dan komplikasi. Salah satu yang kemungkinan dapat dikembangkan sebagai terapi adalah tanaman herbal daun kenikir (Cosmos Caudatus Kunth.) yang banyak mengandung flavonoid. Flavonoid berperan sebagai antioksidan yang dapat mengurangi kerusakan berbagai organ termasuk jantung. Penelitian ini menguji khasiat ekstrak daun kenikir terhadap derajat kerusakan otot jantung tikus model DM yang belum pernah dilaporkan sebelumnya.

Tujuan Penelitian : Penelitian ini bertujuan mengetahui efek kardioprotektif ekstrak daun kenikir pada tikus putih model DM.

Metode : Total 24 ekor tikus putih (Rattus norvegicus) dibagi menjadi 4 kelompok secara acak, yaitu kelompok kontrol normal (KKN) tanpa perlakuan; kelompok kontrol negatif $(\mathrm{KK}(-))$ hanya diinduksi Streptozotocin (STZ $60 \mathrm{mg} / \mathrm{kgBB}$ ) dan Nicotinamid (NA $120 \mathrm{mg} / \mathrm{kgBB}$ ) secara intraperitoneal dosis tunggal pada hari ke-8; serta kelompok perlakuan 1 dan 2 (KP1 dan KP2), diinduksi STZ-NA dan masing-masing diberi ekstrak daun kenikir dosis $200 \mathrm{mg} / \mathrm{kgBB}$ dan $400 \mathrm{mg} / \mathrm{kgBB}$. Setelah 28 hari pemberian ekstrak daun kenikir, gambaran histopatologi jantung tikus diperiksa dan dinilai dengan skor derajat kerusakan. Skor tersebut dianalisis secara statistik dengan uji Kruskal Wallis yang dilanjutkan dengan uji Post Hoc Mann Whitney .

Hasil : Terdapat perbedaan derajat kerusakan histopatologi jantung tikus yang signifikan pada semua kelompok perlakuan. KP2 mempunyai derajat kerusakan yang lebih ringan daripada KK(-) dan KP1.

Kesimpulan : Ekstrak daun kenikir memiliki efek kardioprotektif karena dapat mengurangi derajat kerusakan otot jantung tikus putih model diabetes mellitus.
\end{abstract}

Kata Kunci: efek kardioprotektif; cosmos caudatus kunth.; flavonoid; tikus model DM.

\section{ABSTRACT}

Background: Diabetes Mellitus (DM) is one of the degenetaive disease which cause complication in the body's tissues including heart. Therefore, DM must be adequately treated to prevent the disease progession and its complication. One of the herbs which potentially to develop as diabetic therapy is Kenikir leaf (Cosmos caudatus Kunth.). It is known to have high flavanoids content. Flavonoids are antioxidants that play a role in reducing tissue damage include heart. This study aims to investigate the efficacy of kenikir leaf extract on degree of heart muscle damage in diabetic rat that had been not reported. 


\begin{abstract}
Objective: This study aimed to determine the cardioprotective effect of kenikir leaf extract using the DM rat model.

Methods: The total sample of 24 rats (Rattus norvegicus) were divided into 4 groups, the normal control group (KKn), was not induced by streptozotosin-nicotinamide (STZ-NA) intraperitoneal; negative control group (KK(-)), induced by STZ-NA (STZ $60 \mathrm{mg} / \mathrm{kg} \mathrm{BW}$ and NA $120 \mathrm{mg} / \mathrm{kg} \mathrm{BW);The} \mathrm{treatment} \mathrm{group} 1$ and 2 (KP1 and KP2), were induced by STZ-NA at the same dose as previously mentioned and were given kenikir leaf extract at dose $200 \mathrm{mg} / \mathrm{kg} \mathrm{BW}$ and $400 \mathrm{mg} / \mathrm{BW}$ respectively. The hearth histopathology of rat's were examined on the $28^{\text {th }}$ day after the administration of kenikir leaf extract. The results were statistically analyzed using Kruskal Wallis test followed by Post Hoc Mann Whitney test Results :There were a significant difference in the hearth histopathopogy of rat's in all group. There were minimally heart tissues damage of KP2 group compare to the KK(-) and KPl groups.

Conclusion: The kenikir leaf extract has cardioprotective effect since it was proven to reduce the heart tissue damaged in diabetic rat model.
\end{abstract}

Keywords: cardioprotective effect; cosmos caudatus kunth.; flavonoid; diabetic rat model.

\section{PENDAHULUAN}

Diabetes Mellitus (DM) merupakan masalah kesehatan yang serius karena prevalensinya yang terus meningkat. Saat ini sekitar 500 juta penduduk dunia menderita diabetes dan diperkirakan prevalensinya akan terus meningkat hingga mencapai 700 juta jiwa penduduk dunia pada tahun $2040^{1}$. Pada tahun 2013, tercatat $6,9 \%$ penduduk Indonesia yang berusia di atas 15 tahun menderita DM dan pada tahun 2018 prevalensinya meningkat menjadi $8,5 \%{ }^{2}$.

Diabetes Mellitus ditandai dengan meningkatnya kadar glukosa di dalam darah atau hiperglikemia. Kondisi ini dikarenakan adanya defisiensi produksi insulin oleh sel $\beta$ pankreas dan atau gangguan sensitivitas insulin di jaringan perifer sehingga glukosa tidak dapat digunakan oleh $\mathrm{sel}^{3}$. Hiperglikemia dapat mengakibatkan gangguan proses oksidatif pada tubuh atau disebut dengan stress oksidatif ${ }^{4}$.

Stress oksidatif merupakan kondisi ketidakseimbangan antara jumlah oksidan dan antioksidan dalam tubuh. Hal tersebut dikarenakan produksi radikal bebas seperti Reactive Oxygen Species (ROS) yang berlebihan ${ }^{5}$. Kondisi stress oksidatif pada DM dapat mengakibatkan komplikasi yang serius di berbagai organ tubuh ${ }^{4}$. Organ yang paling sering terkena komplikasi akibat DM adalah mata, saraf, ginjal dan jantung ${ }^{6}$.

Komplikasi DM pada jantung atau yang sering dikenal dengan kardiomiopati diabetik berpotensi menimbulkan gagal jantung sehingga dapat meningkatkan kematian ${ }^{7}$ Kardiomiopati terjadi karena adanya stress oksidatif akibat peningkatan radikal bebas pada otot jantung ${ }^{8}$.

Untuk mencegah timbulnya komplikasi pada pasien DM, maka kadar glukosa darah harus dikontrol. Penatalaksanaan DM bertujuan untuk mempertahankan kadar glukosa darah agar tetap normal yang dapat dilakukan melalui kombinasi perubahan gaya hidup dan terapi farmakologis. Perubahan gaya hidup meliputi pengaturan diet dan olahraga, sedangkan terapi farmakologis meliputi obat antidiabetik oral dan injeksi ${ }^{9}$.

Obat anti diabetik (OAD) yang tersedia saat ini cukup beragam namun masing-masing mempunyai efek samping dan perlu disesuaikan untuk individu dengan kondisi tertentu misalnya usia tua, hamil, 
obesitas dan lain-lain ${ }^{9}$ Oleh karena itu, penelitian untuk menemukan OAD dengan efek samping minimal masih terus dilakukan. Salah satunya penelitian pada tanaman herbal. Obat herbal memiliki beberapa keunggulan dibandingkan dengan obat komersial antara lain mudah didapatkan, efek samping minimal, murah dan eco-friendly ${ }^{10}$.

Daun kenikir (Cosmos Caudatus

Kunth.) merupakan salah satu jenis sayuran dan tanaman herbal yang sering digunakan oleh masyarakat Indonesia. Daun ini mengandung flavonoid yang cukup tinggi ${ }^{11}$. Penelitian sebelumnya menunjukkan bahwa tanaman herbal yang mengandung flavonoid mampu menurunkan kadar glukosa darah pada tikus model DM ${ }^{12}$. Selain itu flavonoid berperan sebagai antioksidan yang dapat mengurangi stress oksidatif akibat hiperglikemia pada DM sehingga dapat mencegah kerusakan berbagai organ termasuk jantung ${ }^{13}$. Banyak penelitian mengenai ekstrak daun kenikir yang telah dilakukan namun sejauh pengetahuan peneliti, penelitian tentang khasiat ekstrak daun kenikir terhadap jantung tikus model DM khususnya terhadap derajat kerusakan otot jantung belum pernah dilakukan.

Berdasarkan uraian diatas, peneliti bertujuan mengetahui efek kardioprotektif ekstrak daun kenikir (Cosmos Caudatus Kunth.) terhadap jantung tikus model DM. Model DM dibuat dengan cara menginduksi tikus dengan Streptozotosin dan nikotinamid (STZ-NA).

\section{METODE}

Penelitian ini merupakan penelitian eksperimental laboratorik dengan desain Posttest Only Control Group Design. Ethical Clearance penelitian didapat dari Komite Etik Fakultas Kedokteran Universitas Sebelas Maret Surakarta dengan nomor 304/UN27.6/KEPK/2018.
Subyek penelitian adalah tikus putih (Rattus norvegicus) galur wistar dengan kriteria inklusi berkelamin jantan, usia 2-3 bulan dan berat 200-250 gram. Kriteria eksklusi, tikus putih yang cacat fisik, tampak sakit, kadar glukosa darah puasa pada 3 hari sesudah induksi streptozotosin dan nikotinamid $\leq 126 \mathrm{mg} / \mathrm{dL}$, serta tikus yang mati selama penelitian.

Penelitian ini menggunakan ekstrak daun kenikir yang didapat dari CV.Merapi Farma Yogyakarta dalam bentuk simplisia. Simplisia diekstraksi dengan metode maserasi menggunakan pelarut ethanol $80 \%$ berulang kali dan sesekali dikocok. Proses ekstraksi berlangsung sekitar 2 minggu. Setiap 2 hari sekali pelarut diganti dan disaring untuk mendapatkan liquid extract. Selanjutnya liquid extract dievaporasi menggunakan vacuum rotary evaporator untuk medapatkan ekstrak yang kental.

Jumlah total sampel penelitian yaitu 24 ekor tikus yang dibagi secara acak menjadi 4 kelompok, masing-masing kelompok terdiri dari 6 ekor tikus. Empat kelompok tersebut adalah kelompok kontrol normal (KKN), kelompok kontrol negatif (KK(-)), kelompok perlakuan 1 dan 2 (KP1 dan KP2).

Sebelum perlakuan, hewan coba diadaptasikan terlebih dahulu selama 7 hari. Selama percobaan, KKN hanya diberi pakan standar dan air ad libitum; KK(-) diberi pakan standar dan diinduksi menjadi tikus model diabetes dengan STZ-NA pada hari ke-8 percobaan. Induksi dilakukan secara injeksi intraperitoneal dengan dosis STZ 60 $\mathrm{mg} / \mathrm{kgBB}$ dan NA $120 \quad \mathrm{mg} / \mathrm{kgBB}$. Nikotinamid diberikan 15 menit sebelum injeksi STZ. Kelompok KP1 dan KP 2, diberi pakan standar, diinduksi STZ-NA pada hari ke 8 dan diberi ekstrak daun kenikir dengan dosis berturut-turut $200 \mathrm{mg} / \mathrm{kg}$ BB dan 400 $\mathrm{mg} / \mathrm{kg}$ BB. Ekstrak daun keningkir pada kedua kelompok diberikan dengan sonde lambung selama 28 hari (hari ke-12 sampai 
hari ke-39). Sebelum induksi STZ-NA (pada hari ke-8 percobaan), tikus pada semua kelompok diambil darahnya dari vena retro orbital untuk dilakukan pemeriksaan glukosa darah puasa.

Tiga hari setelah induksi STZ-NA, yaitu hari ke-11, glukosa darah puasa kembali diperiksa untuk mengetahui apakah induksi tikus model DM telah berhasil. Tikus tergolong DM dan disertakan pada penelitian jika kadar glukosa puasanya $\geq 126 \mathrm{mg} / \mathrm{dL}$.

Setelah 28 hari pemberian ekstrak daun kenikir (hari ke-40 percobaan), hewan coba pada semua kelompok diperiksa glukosa darah puasanya dan dilakukan terminasi.

Selanjutnya organ jantung tikus diambil untuk dibuat preparat jaringan yang dicat dengan pewarnaan hematoksilin eosin (HE). Setiap tikus dibuat 4 irisan/preparat jaringan dan setiap preparat diukur persentase kerusakannya pada 2 lapang pandang sehingga total terdapat 48 pengamatan pada setiap kelompok.

Persentase kerusakan diklasifikan menjadi 4 derajat yaitu derajat 0 menunjukkan tidak ada kerusakan, derajat 1 apabila ditemukan kerusakan 0-30\%, derajat 2 menunjukkan kerusakan sebesar 30-60\% dan derajat 4 menunjukkan kerusakan $>60 \%$. Kerusakan ditandai dengan adanya inflamasi/infiltrasi sel radang pada lapisan miokardium dan eosinofilia pada sitoplasma sel otot jantung ${ }^{14}$. Pemeriksaan histopatologi jantung tersebut diamati dengan menggunakan mikroskop cahaya perbesaran 400x.

Perbandingan perbedaan derajat kerusakan setiap kelompok dianalisis dengan uji Kruskal Wallis yang dilanjutkan dengan uji Post Hoc Mann Whitney. Derajat kemaknaan yang digunakan adalah $\alpha=0,05$ dan dinyatakan bermakna apabila nilai $\mathrm{p}<0,05$.

\section{HASIL}

A. Kadar glukosa darah puasa tikus

Pengukuran kadar glukosa darah puasa tikus putih sebanyak 3 kali. Pengukuran pertama dilakukan pada hari ke-8, tepat sebelum induksi streptozotosin dan nikotinamid dengan tujuan untuk memastikan bahwa tikus yang akan diinduksi tidak menderita DM. Pada hari ke-11 dilakukan pengukuran kedua kadar glukosa darah puasa tikus putih untuk mengkonfirmasi keberhasilan induksi DM pada tikus putih. Pengukuran ketiga dilakukan pada hari ke-40 untuk memastikan keadaan DM dipertahankan hingga akhir penelitian. Rerata kadar glukosa darah puasa setiap kelompok ditampilkan pada tabel 1 .

Tabel 1. Rerata Kadar Glukosa Darah Puasa Tikus Putih (Rattus norvegicus) pada Masing-Masing Kelompok

\begin{tabular}{lccc}
\hline Kel Kelompok & $\begin{array}{l}\text { Rerata Kadar Glukosa } \\
(\mathrm{mg} / \mathrm{dL})\end{array}$ & Darah Puasa & Standar Deviasi \\
& Hari ke-8 & Hari Ke-11 & Hari Ke-40 \\
\hline KKN & $71,45 \pm 5,26$ & $72,83 \pm 5,11$ & $73,76 \pm 5,09$ \\
KK(-) & $69,68 \pm 4,73$ & $257,36 \pm 4,37$ & $259,21 \pm 4,57$ \\
KP1 & $69,34 \pm 3,47$ & $258,29 \pm 2,83$ & $125,27 \pm 3,97$ \\
KP2 & $70,42 \pm 4,06$ & $256,92 \pm 2,35$ & $101,76 \pm 4,21$ \\
\hline
\end{tabular}

Hasil pengukuran kadar glukosa darah pada tabel 1 menunjukkan bahwa rerata kadar glukosa darah puasa sebelum induksi STZNA pada hari ke-8 dari tiap kelompok perlakuan tidak jauh berbeda dan dalam batas normal $(<126 \mathrm{mg} / \mathrm{dL})$.

Pemeriksaan kadar glukosa darah puasa pada hari ke-11 menunjukkan kenaikan kadar glukosa darah (>126 mg/dl) pada 
kelompok yang diinduksi STZ-NA, yaitu kelompok $\mathrm{KK}(-)$, KP1, dan KP2 sehingga dapat disimpulkan injeksi STZ-NA berhasil sebagai induksi tikus model diabetes melitus tipe II pada semua hewan uji di penelitian ini.

Pemeriksaan kadar glukosa darah puasa yang ketiga (hari ke-40) menunjukkan rerata kadar glukosa darah puasa pada KKN tidak menunjukkan kenaikan dibandingkan pengukuran pada hari ke-8 dan ke-11. Pada $\mathrm{KK}(-)$ yang tidak diberikan ekstrak daun kenikir (Cosmos caudatus Kunth.), tidak terdapat penurunan rerata kadar glukosa darah puasa. Kelompok yang diberikan ekstrak daun kenikir (Cosmos caudatus Kunth.), yaitu KP1 dan KP2 menunjukkan penurunan rerata kadar glukosa darah puasa.

\section{B. Histopatologi Otot Jantung}

Gambaran histopatologi otot jantung yang dicat dengan hematoksilin dan eosin pada KKN, KK(-), KP1 dan KP2 dapat dilihat pada gambar 1. Pada KKN, sebagian besar sampel tidak menunjukkan kerusakan pada gambaran histopatologi jantungnya sedangkan pada KK(-) sebagian besar menunjukkan kerusakan derajat 2 dan 3. Sebagian besar sampel KP1 dan KP2 menunjukkan kerusakan derajat 1.

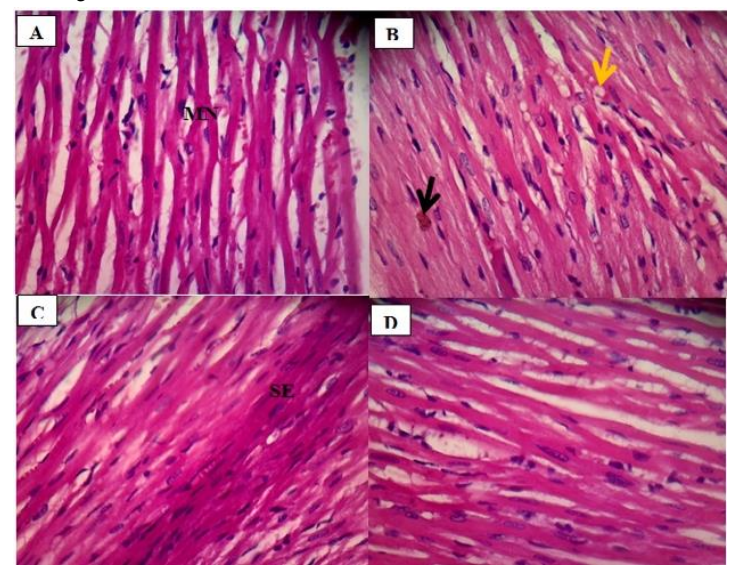

Gambar 1. Histopatologi Otot Jantung. A. Kelompok kontrol normal (KKN). B. Kelompok kontrol negatif $(\mathrm{KK}(-))$. C. Kelompok perlakuan 1 (KP1). D. Kelompok Perlakuan 2 (KP2). MN = myocardium normal, $\mathrm{SE}=$ Sitoplasma eosinofilia, panah hitam = inflamasi, panah kuning = vakuolisasi. Pengecatan H\&E. Pembesaran 400x.

Jumlah dan persentase derajat kerusakan histopatologi jantung tikus putih pada 48 pengamatan dari tiap kelompok dapat dilihat pada tabel 2 .

Tabel 2. Jumlah dan persentase derajat kerusakan otot jantung tikus putih

\begin{tabular}{lrrrrr}
\hline \multirow{2}{*}{ Kelompok } & \multicolumn{4}{c}{ Jumlah dan Persentase Derajat kerusakan } & \multicolumn{2}{c}{ Total } \\
& \multicolumn{1}{c}{ Derajat 0 } & \multicolumn{1}{c}{ Derajat 1 } & \multicolumn{1}{c}{ Derajat 2 } & \multicolumn{1}{c}{ Derajat 3 } & \\
\hline KKN & $38(79,2 \%)$ & $10(20,8 \%)$ & $0(0 \%)$ & $0(0 \%)$ & $48(100 \%)$ \\
KK(-) & $1(2 \%)$ & $9(18,8 \%)$ & $20(41,6 \%)$ & $18(37,5 \%)$ & $48(100 \%)$ \\
KP1 & $8(16,7 \%)$ & $30(62,5 \%)$ & $10(20,8)$ & $0(0 \%)$ & $48(100 \%)$ \\
KP2 & $24(50 \%)$ & $24(50 \%)$ & $0(0 \%)$ & $0(0 \%)$ & $48(100 \%)$ \\
\hline
\end{tabular}

Pada tabel 2 terlihat luas kerusakan histopatologi jantung derajat 0 paling banyak terdapat pada KKN yaitu sebesar 79,2\%, sedangkan derajat 3 paling banyak pada KK(-) yaitu sebesar 37,5\%. Pada KP1 sebagian besar kerusakan terjadi pada derajat 1 , yaitu sebesar $62,5 \%$ dan pada KP2 terjadi kerusakan dengan derajat 1 sebanyak $50 \%$ sampel sedangkan sisanya tidak mengalami kerusakan (derajat 0).

C. Analisis statistik

Analisis derajat kerusakan preparat histopatologi jantung tikus pada keempat kelompok perlakuan yaitu kelompok kontrol negatif $(\mathrm{KK}(-))$, kelompok kontrol normal $(\mathrm{KKN})$, kelompok perlakuan 1 (KP1) dan kelompok perlakuan 2 (KP2) dengan uji 
Kruskal-Wallis menunjukkan perbedaan yang signifikan $(\mathrm{p}=0,000 ; \mathrm{p}<0,05)$.

Uji Post Hoc Mann Whitney menunjukkan terdapat perbedaan derajad kerusakan histopatologi jantung tikus yang signifikan diantara kelompok perlakuan (KK() dengan $\mathrm{KKN}(\mathrm{p}=0,000), \mathrm{KK}(-)$ dengan $\mathrm{KP} 1$ $(\mathrm{p}=0,000), \mathrm{KK}(-)$ dengan KP2 $(\mathrm{p}=0,003)$, KKN dengan KP1 $(p=0,000)$, KKN dengan $\mathrm{KP} 2 \quad(\mathrm{p}=0,000)$ dan KP1 dengan KP2 $(\mathrm{p}=0,000)$.

\section{PEMBAHASAN}

Pada penelitian ini tidak ada hewan coba yang mati pada semua kelompok perlakuan. Semua hewan coba pada KP1 dan KP2 yang tetap hidup sampai akhir penelitian menunjukkan bahwa ekstrak daun kenikir yang dikonsumsi hewan coba masih dalam dosis yang tidak berefek letal.

Pengukuran kadar glukosa darah puasa tikus putih pada hari ke-8 menunjukkan kadar glukosa darah puasa masing-masing kelompok masih dalam batas normal sebagaimana tertera pada tabel 1 . Hal ini menunjukkan tidak ada tikus yang menderita DM sebelum dilakukan induksi.

Pengukuran kadar glukosa darah puasa tikus pada hari ke-11 bertujuan untuk mengkonfirmasi keberhasilan induksi tikus model diabetes melitus pada KK(-), KP1, dan KP2. Pada pengukuran hari ke-11 diperoleh rata-rata kadar glukosa darah puasa pada ketiga kelompok tersebut $>126 \mathrm{mg} / \mathrm{dL}$ (tabel 1). Hal ini menunjukkan induksi DM pada tikus berhasil.

Strepzotocin dan nikotinamid yang digunakan dalam penelitian ini berhasil menginduksi kondisi DM tipe II pada tikus putih (Rattus norvegicus). Streptozotosin (STZ) menyebabkan kerusakan sel $\beta$ pankreas melalui ikatan dengan transporter glukosa GLUT-2 pada membran plasma yang kemudian akan menyebabkan mekanisme stress oksidatif ${ }^{15}$. Strepzotocin merusak sel $\beta$ dengan cara mengaktifkan enzim PARP-1 yang akan mengurangi stok NAD+ di dalam sel $\beta$ yang diperlukan dalam proses pembentukan ATP. Berkurangnya stok NAD+ di dalam sel $\beta$ akan mengganggu proses pembentukan ATP oleh sel $\beta$ tersebut, kemudian menyebabkan kematian sel $\beta$ pada pankreas. Nikotinamid (NA) berefek sebaliknya yaitu melindungi sel $\beta$ pankreas terhadap efek toksik $\mathrm{STZ}^{16}$ sehingga sel $\beta$ pankreas tikus model DM masih dapat mensekresi insulin walaupun dalam jumlah yang tidak adekuat ${ }^{17}$. Nikotinamid melindungi sebagian sel $\beta$ dari kerusakan akibat streptozotosin dengan cara menghambat enzim PARP- ${ }^{16}$. Rusaknya sebagian sel $\beta$ pankreas ini mengakibatkan kondisi DM tipe II pada tikus putih.

Kadar glukosa darah puasa kelompok KK(-) pada hari ke-40 tidak jauh berbeda bila dibandingkan dengan kadar glukosa darah puasa pada hari ke-11 (tabel 1). Hal tersebut menunjukkan bahwa pembuatan tikus model diabetes melitus dengan induksi streptozotosin - nikotinamid berhasil dipertahankan hingga akhir penelitian. Sedangkan pada kelompok KP1 dan KP2 terdapat penurunan kadar glukosa darah puasa pada hari ke-40 yaitu $125,27 \mathrm{mg} / \mathrm{dL}$ pada KP1 dan 101,76 mg/dL pada KP2 (tabel 1) yang berarti bahwa pemberian ekstrak daun kenikir pada penelitian ini dapat menurunkan kadar glukosa darah puasa tikus putih model DM.

Gambaran histopatologi otot jantung tikus putih (Rattus norvegicus) model DM tipe II yang diamati pada penelitian ini adalah derajat kerusakan otot jantung dalam satu lapang pandang yang dinilai dengan skoring. Pada hasil pengamatan didapatkan persentase otot jantung yang tidak mengalami kerusakan pada KKN sebesar 79,2\% dan yang mengalami kerusakan derajat 1 adalah 20,8\%. Hal ini menunjukkan bahwa KKN mengalami kerusakan yang paling minimal dibandingkan 
dengan kelompok perlakuan lainnya. Gambaran histopatologi jantung pada KKN ini dapat terjadi karena variabel luar yang tidak dapat dikendalikan. Gambaran awal histologis jantung pada penelitian ini tidak diperiksa sehingga terdapat kemungkinan otot jantung sudah mengalami kerusakan sebelum pemberian perlakuan.

Histopatologi $\mathrm{KK}(-)$ menunjukkan sebagian besar $(41.6 \%)$ mengalami kerusakan derajat 2, dan sisanya mengalami kerusakan derajat 3 sebanyak $37,5 \%$ dan kerusakan derajat 1 sebanyak $18,8 \%$. Kerusakan dengan derajat 0 pada $\mathrm{KK}(-)$ terjadi pada 1 sampel (2\%). Hal ini menunjukkan sampel pada KK() mengalami kerusakan yang paling berat diantara kelompok perlakuan lainnya.

Kelompok Perlakuan 1 (KP1) dan Kelompok Perlakuan 2 (KP2) yang diberi ekstrak daun kenikir (Cosmos caudatus Kunth.) setelah induksi streptozotosinnikotinamid menunjukkan derajat kerusakan yang lebih ringan dibandingkan $\mathrm{KK}(-)$. Hal ini menunjukkan bahwa ekstrak daun kenikir (Cosmos caudatus Kunth.) dapat berperan mengurangi derajat kerusakan otot jantung pada tikus putih (Rattus norvegicus).

Berdasarkan uji Post Hoc Mann Whitney, $\mathrm{KK}(-)$ dan KKN memiliki perbedaan yang signifikan $(\mathrm{p}=0,000)$. Gambaran histopatologi yang terjadi pada $\mathrm{KK}(-)$ menunjukkan kerusakan yang jauh lebih berat dibandingkan dengan KKN. Hal ini menunjukkan bahwa pembuatan sampel model diabetes melitus menggunakan induksi STZ-NA berdampak kerusakan pada histopatologi jantung tikus putih. Hal ini sesuai penelitian Badole et al (2014) dan Guido et al (2017) yang menunjukkan bahwa induksi STZ-NA dapat menyebabkan kerusakan struktur histologis lapisan miokardium jantung ${ }^{14,18}$. Kerusakan yang terjadi berupa inflamasi lapisan otot jantung, eosinofilia pada sitoplasma sel otot jantung, vakuolisasi dan rusaknya struktur otot jantung. Hal ini disebabkan karena streptozotosin (STZ) yang masuk ke dalam sel $\beta$ pankreas akan menyebabkan stress oksidatif dan inflamasi sistemik yang dapat memicu peningkatan $\operatorname{ROS}^{19,20}$. Reactive Oxygen Species (ROS) memiliki peran penting dalam patofisiologi kerusakan struktur histologis jantung. Reactive Oxygen Species (ROS) dapat menimbulkan ekspresi gen yang abnormal dan perubahan transduksi sinyal sehingga terjadi peningkatan kerusakan otot jantung ${ }^{20,21}$.

Hasil analisis derajat kerusakan otot jantung antara KK(-) dengan KP1 dan KK(-) dengan KP2 yang menunjukkan perbedaan yang bermakna. Hal ini menunjukkan bahwa ekstrak daun kenikir dapat mencegah kerusakan otot jantung pada tikus model DM. Efek daun kenikir (Cosmos caudatus Kunth.) tersebut dikarenakan daun kenikir mengandung zat flavonoid yaitu quercetin dan kaempferol $^{11}$. Flavonoid dapat menghambat pembentukan radikal bebas dengan cara menghambat aktivitas enzim atau berikatan dengan zat yang berperan dalam pembentukan radikal bebas ${ }^{22}$.

Derajat kerusakan histopatologi otot jantung antara KKN dengan KP1 dan KKN dengan KP2 menunjukkan hasil perbedaan yang signifikan pada uji post hoc. Hal ini menunjukkan histopatologi otot jantung pada KP1 dan KP2 belum sesuai dengan gambaran normal (KKN). Kondisi tersebut kemungkinan disebabkan dosis ekstrak daun kenikir yang diberikan pada KP1 dan KP2 belum optimal untuk mencegah kerusakan otot jantung.

Gambaran histopatologi otot jantung antara KP1 dan KP2 berbeda secara bermakna. Hal ini menunjukkan peningkatan dosis daun kenikir pada penelitian ini dapat berpotensi mencegah kerusakan otot jantung tikus putih. 


\section{KESIMPULAN}

Pemberian ekstrak daun kenikir dapat menurunkan kadar glukosa darah puasa dan mempunyai efek kardioprotektif pada tikus putih model diabetes mellitus.

\section{UCAPAN TERIMA KASIH}

Penulis mengucapakan terima kasih kepada Laboran Pusat Studi Pangan dan Gizi, PAU Universitas Gadjah Mada dan Staf Laboratorium Histologi yang telah membantu persiapan dan penyediaan laboratorium.

\section{DAFTAR PUSTAKA}

1. International Diabetes Federation. Idf diabetes atlas Ninth edition. 2019.

2. Riskesdas. Laoran Nasional Riskesdas 2018.pdf. Jakarta: Badan Peneltian dan Pengembangan Kesehatan; 2018.

3. Association AD. Diagnosis and Classi fi cation of Diabetes Mellitus. Diabetes Care. 2014;37(Supplement 1):81-90.

4. Giacco F, Brownlee M. Oxidative stress and diabetic complication. 2010;107(9):105870.

5. Francisqueti FV, Chiaverni LCT, Dos Santos KC, Minatel IO, Ronchi CB, Ferron AJT, et al. The role of oxidative stress on the pathophysiology of metabolic syndrome. Rev Assoc Med Bras. 2017;63(1):85-91.

6. Chawla A, Chawla R, Jaggi S. Microvasular and macrovascular complications in diabetes mellitus: Distinct or continuum? Indian $\mathrm{J}$ Endocrinol Metab. 2016;20(4):547-51.

7. Kobayashi S, Liang Q. Biochimica et Biophysica Acta Autophagy and mitophagy

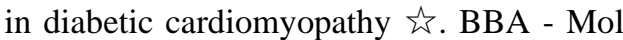
Basis Dis [Internet]. 2015;1852(2):252-61. Tersedia pada: http://dx.doi.org/10.1016/j.bbadis.2014.05.0 20

8. Li C, Zhang Q, Li M, Zhang J, Yu P, Yu D. Attenuation of myocardial apoptosis by alpha-lipoic acid through suppression of mitochondrial oxidative stress to reduce diabetic cardiomyopathy. Chin Med J (Engl). 2009;122(21):2580-6.

9. Marín-peñalver JJ, Martín-timón I, Sevillano-collantes C, del Cañizo-gómez FJ.
Update on the treatment of type 2 diabetes mellitus. World J Diabetes. 2016;7(17):354-95.

10. Verma S, Gupta M, Popli H, Aggarwal G. Diabetes Mellitus Treatment Using Herbal Drugs. Int J Phytomedicine. 2018;10(1):110.

11. Andarwulan N, Batari R, Agustini D, Bolling B, Wijaya H. Flavonoid content and antioxidant activity of vegetables from Indonesia. Food Chem [Internet]. 2010;121(4):1231-5. Tersedia pada: http://dx.doi.org/10.1016/j.foodchem.2010.0 1.033

12. Sholikah TA, Wulandari S, Ariesta I, Hakim MAR, Hafizhan M. Jurnal Kedokteran dan Kesehatan Indonesia. JKKI. 2020;11(2):172-9.

13. Pietta P. Flavonoids as Antioxidants. J NatProd. 2000;63:1035-42.

14. Badole SL, Jangam GB, Chaudhari SM, Ghule AE, Zanwar AA. L-Glutamine Supplementation Prevents the Development of Experimental Diabetic Cardiomyopathy in Streptozotocin-Nicotinamide Induced Diabetic Rats. 2014;9(3):1-7.

15. Lenzen $S$. The mechanisms of alloxan- and streptozotocin-induced diabetes. Diabetologia. 2008;51:216-26.

16. Szkudelski T. Streptozotocin nicotinamide-induced diabetes in the rat . Characteristics of the experimental model. Exp Biol Med. 2012;237:481-90.

17. Masiello P. Animal models of type 2 diabetes with reduced pancreatic $\mathrm{B}$-cell mass. Int $\mathrm{J}$ Biochem Cell Biol. 2006;38:873-93.

18. Guido MC, Marques AF, Tavares ER, Melo MDT De, Salemi VMC, Maranhão RC. The Effects of Diabetes Induction on the Rat Heart: Differences in Oxidative Stress, Inflammatory Cells, and Fibrosis between Subendocardial and Interstitial Myocardial Areas. Oxid Med Cell Longev. 2017;1-11.

19. Cai L, Kang YJ. Oxidative Stress and Diabetic Cardiomyopathy A Brief Review. Cardiovasc Toxicol. 2001;1(3):181-93.

20. Maritim AC, Sanders RA, Iii JBW. Diabetes , Oxidative Stress, and Antioxidants: A Review. J Biochem Mol Toxicol. 2003;17(1):24-38.

21. Yao P, Li K, Jin Y, Song F, Zhou S, Sun X, et al. Food Chemistry Oxidative damage after chronic ethanol intake in rat tissues: Prophylaxis of Ginkgo biloba extract. Food Chem. 2006;99:305-14. 
Sholikah et al., Efek Kardioprotektif Ekstrak Daun Kenikir (Cosmos Caudatus Kunth.) pada Tikus Putih (Rattus norvegicus) Model Diabetes Mellitus

22. Kumar S, Pandey AK. Chemistry and Biological Activities of Flavonoids: An Overview. Sci World J. 2013;1-16. 